\title{
Pierre Bourdieu on social transformation, with particular reference to political and symbolic revolutions
}

\author{
Bridget Fowler ${ }^{1}$
}

Published online: 6 February 2020

(C) The Author(s) 2020

\begin{abstract}
This article challenges what is now the orthodoxy concerning the heritage of Bourdieu (1930-2002): namely, the judgement that his distinctive sociological innovation has been his theory of social reproduction, and that he has failed to provide a necessary theory of social change. Yet Bourdieu consistently claimed to offer a theory of social transformation as well as accounting for continuities of power. Indeed, he provides two substantive keys for an understanding of historical transformation-first, a theory of prophets (religious or secular) as the authors of heresies or "symbolic revolutions" that dispel current doxa; second, a theory of the "corporatism of the universal": the role of intellectuals or other educated professionals in pursuit of social justice and other universalistic goals. Moreover, Bourdieu fuses his theories of "symbolic revolutions" with a materialist analysis of their social preconditions, including a fresh account of social crises. Crises - war, famine, recession, and especially the intensified precarity of the educated - have, for him, a profound impact, both within differentiated fields and across fields. Conflicts that become effectively synchronized across fields acquire great resonance within the wider field of power, particularly due to hysteresis or "maladjusted habitus." Indeed, the appearance of crises, together with new prophetic heresies, leads the subordinate classes to question the taken-for-granted order of things and to orchestrate their resistance. Alongside his corpus of published writings, this article draws widely on Bourdieu's posthumously published lectures. These cast a distinctive new light on how his well-known conceptual instruments can aid us in the study of historical change. They also expand on how social science itself might be used to facilitate progressive social movements.
\end{abstract}

Keywords Elite reproduction · Heterodoxy $\cdot$ Intellectuals $\cdot$ Prophets $\cdot$ Revolutions $\cdot$ Social transformation

I should like to express my gratitude to Matt Dawson and Andrew Smith of Glasgow University, Roy Enfield and the anonymous peer reviewers and Editors of Theory and Society for helpful advice in revising this article.

Bridget Fowler

Bridget.Fowler@glasgow.ac.uk

Extended author information available on the last page of the article 
In 2001, Pierre Bourdieu attended a colloquium at Cerisy-la-Salle in his honour, to which I was invited. With the memorable exception of Tassadit Yacine, the conference gathered together only his "foreign researchers." This was due to Bourdieu's embattled status within France, as indicated by the savage criticism of Verdès-Leroux (1998), Heinich (2007), and Latour (2007). These bitter Parisian culture wars continue to rage: see, for example, Jean-Louis Fabiani's erudite but profoundly disenchanted study, Pierre Bourdieu: Un structuralisme heroïque (2016) and the important rebuttal in Joly's Pour Bourdieu (2018).

As is well-known, Bourdieu extended the relational concept of economic capital found in Marx to cultural, social and symbolic capitals. He thus provides a valuable insight into the resources available for dominant actors in late capitalism. In particular, he has updated Weber so as to show the roles of education in modernity, not least the symbolic intimidation of the subordinate classes by the dominant class who possess legitimate cultural capital. Such educational accreditation operates with the logic of a status group, yet, as Swartz illuminatingly remarks: “[...] Bourdieu develops a general argument to show that status functions to disguise class interests" (Swartz 1998, p. 150, also p. 184).

The symbolic profits of cultural capital are typically converted into economic capital, not least, the mega-salaries of corporate employers. By World War II, certified cultural capital ${ }^{1}$ had become a prerequisite for many higher professional, bureaucratic, and corporate jobs, although in many fields, additional social capital (influential patrons) might also be required (Bourdieu 1996b, p. 142). Bourdieu and his colleagues refer to this as the "new mode of reproduction" within the dominant class, showing the decline of direct economic inheritance and its mediation instead via cultural capital (Bourdieu and Boltanski 1978, pp. 220-221). In general, only those from the dominant class possess the "primary pedagogy" and hence the habitus to benefit appreciably from the secondary pedagogies in school (Bourdieu 1984, pp. 479, 571; Bourdieu 1996b; Bourdieu and Passeron 1990, pp. 31-51). Yet given that the educational system is deployed "neutrally" to reproduce not just the educators but also the occupants of the most powerful jobs elsewhere, the subordinate classes typically "misrecognise" their failure as due to their individual weaknesses (Bourdieu and Passeron 1990, pp. 204 205). The educational system in this "logic of practice" thus constitutes a new legitimatory "sociodicy," as profoundly effective as those "theodicies" described by Weber, namely the Indian Hindu karma system and the salvation promise for deserving Christians (1990, p. 208).

Several theorists have taken issue with Bourdieu's theoretical analysis of the logic of practice, developed here and elsewhere (most notably, 1990a). Fabiani (2016, p. 83) and Michael Burawoy, for example, claim - mistakenly, in my view - that Bourdieu's distinctive concept of habitus is merely a rhetorical "black box," "unverifiable and unknowable," a mystifying disguise cloaking workers and peasants' allegedly fatalistic

\footnotetext{
"I share Lareau and Weininger's contention (2003) that the "dominant interpretation" linking cultural capital to knowledge of "highbrow" cultural pursuits is too restrictive. Rather, as Bourdieu suggests, such capital entails "competences" such as reading at home, or classificatory skills that enable the appropriation of a given societal heritage. Crucially these relate to "the educational norms of the classes capable of imposing the ... criteria of evaluation which are the most favourable for their children" (Lareau and Weininger 2003, p. 588).
} 
adjustment to the world (Burawoy 2012, p. 204, Burawoy and Holdt 2012). He is criticized widely for insufficient rigour in showing precisely how the habitus offers a non-reductive account of actors' dispositions, given that differing trajectories and improvised practices are sieved first through the "historical unconscious" of family and class experiences (Bourdieu 1990a, pp. 56, 60). Further, Alex Callinicos, like Craig Calhoun, argues that Bourdieu's sociology has a "relatively weak conception of systemic contradiction" (Callinicos 2006, p. 82; Calhoun 1995, p. 141), whilst for Scott and Wacquant (1987) it is lacking in any resources to conceptualize peasant or working-class resistance in the face of oppression (Scott 1987, pp. 323-325). Even David Swartz, who is favourably disposed, concludes his initial, highly perceptive, book by regretting Bourdieu's failure to "assemble [...] a general theory of social change" (1998, p. 217):

Bourdieu's understanding of the dynamics of social life in advanced societies is one of structural permutations rather than of structural transformation; one of market competition, not collective organisation; and one of reproduction, not revolution (1998, p. 188)

Against the grain of such criticisms, I would endorse Swartz's recent claim that Bourdieu does have a theory that is "conceptually open to elements of change" (2013, p. 244). Indeed, from his studies of the Algerian "cauldron" onwards, Bourdieu was concerned with two particular transformations: first, the transition from a closed peasant world to capitalist modernity, dominated by an "economy for its own sake" and secondly, the transition to an urban, industrialised society in which a stable workingclass typically develops collective, future-oriented action (2008a [1962], pp. 120-121). Of course, a great merit of his theory is its unrivalled account of the dominants' capacities in France to perpetuate their advantages over time, especially by the skilful adaptation of capitals from one type to another. ${ }^{2}$ On that score, he has been sensitive, for example, to the conflict of generations within certain social fields, which, paradoxically, may serve only to conserve the general hierarchies and material inequalities.

Nevertheless, I propose that Bourdieu's sociology does allow for emancipatory action, by addressing actors' encounters with heterodox discourses, as well as by specifying their conditions of possibility. ${ }^{3}$ His sociology has consistently possessed a rich subtext that offers theoretical resources for analysing actors' critique, resort to heterodox beliefs and engagement in transformative societal change, both at field and

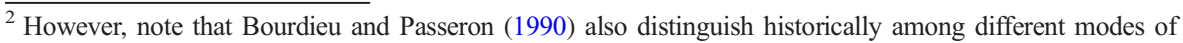
reproduction: the privately-educated feudal aristocracy, the Jesuit colleges of the seventeenth century gentleman (honnête homme), and the lycées and grandes écoles of the nineteenth century bourgeoisie.

${ }^{3}$ I agree with Swartz's earlier view when he distinguishes the elements that constitute a Bourdieusian analysis of social change, amongst them the "intrusion of external events into fields," "uneven development and conjuncture of crises amongst different fields," and "social struggles that expose field doxa ..." (1998, p. 217). But Swartz also argues that "these have yet to be assembled into a general theory [...]" (1998, p. 217), agreeing with Wacquant that: "these [variables] never assume more than the status of isolated negative specifications (how reproduction breaks down) rather than the elements of a systematic model of structural change (how transformation occurs)" (Wacquant 1987, p. 81). Swartz's later book (2013) significantly modifies this position. Nevertheless, it seems to me that he - along with Burawoy, Scott, and Wacquantconsistently underestimate the value of Bourdieu's theory of change.
} 
societal levels (Bourdieu and Wacquant 1990, pp.102,109, 132-7). In Gorski's graphic words (2013, p. 2): "the concern with historical change is a red thread, sometimes thicker, sometimes thinner, that traverses his entire life's work." I seek to demonstrate this, with particular reference to his recently-published Collège de France lectures: Manet: une révolution symbolique (2013), On the State (2014), and Sociologie générale Vol. I (2015) and Vol. II (2016). ${ }^{4}$

For the late Bourdieu—hostile to "chic relativism" (2000a, p. 71) - transformation is linked to invitations to "reflexivity" (Bourdieu and Wacquant 1992). In this respect, Bourdieu might be seen as the last of a long line of philosophers who advocate deliberation to understand how they should act in the world. Yet for him, as for Gouldner (1971, pp. 488-512), such reflexivity needs to be guided by empiricallygrounded social science $(1984$, p. 94). This alone can combine a methodology for revealing the historical genesis and character of the structures determining practice ("objectivation") together with explorations of the subjective "perspectives," "eye," or meanings shaped by actors' positions within various fields. Importantly, against Calhoun and Callinicos, Bourdieu's sociological approach elucidates the inner contradictions within such fields, including the encompassing meta-field of class power (1978, p. 168). He had noted by the early 1980 s, for example, that fields are bisected by resistance to the symbolic power of the more consecrated dominants within them (1987b; 1991a; 1993; 2015, pp. 540-545).

His account of crises ramifying through an entire society and initiating historical transformation starts from Weberian studies, especially linked to those crises that heighten pre-existing conflicts between prophets and priests (Weber 1978, pp. 439457). Such an analysis emerged first in the context of Bourdieu's ethnography of the Algerian War. His research for this emphasized the land seizures-ratified in the colonial laws of 1871-1873-accompanying the imposition on Algerians of both French capitalism and the European dominant "caste" (2008a, pp. 126, 126-150), an abrupt shift from a "mechanical" to an "organic" division of labour. But if, for the traditional pre-capitalist Algerian peasantry, this was the "end of a world," it was also accompanied by the gathering movement of Algerian rebellion, interpreted and led by secular "prophets." In this case, they were Kabylian oral poets ${ }^{5}$ and writers: prominent amongst them: Mouloud Feraoun (1962), Malek Ouary and Mouloud Mammeri (2008a, pp. 125-137; Bourdieu and Mammeri, in Bourdieu 2008a).

Crucially, in his chapter on the French May 1968 "events" in Homo Academicus [1988], Bourdieu gives us a general analysis of revolution, although a revolution effectively repressed. He shows that the initial conflict was most explosive within the expanding but relatively autonomous university field, due to new staff with a different habitus and lower qualifications, the devaluation of degrees and the growth of the social sciences (2015, pp. 477-479). The original site of revolutionary collision was then

\footnotetext{
${ }^{4}$ The initial lectures of Sociologie Générale I, from April-June 1982, have now been translated into English as Classification Struggles (2019).

5 "And we in Algeria are present at this end of a world," he remarks, observing that "A society so thoroughly turned upside down will force the invention of revolutionary solutions and mobilise these masses [...] by offering them a new art of living" (2008b [1961], pp. 12-13) [translation altered in light of 2000a, pp. 136137: translations from French are by me.] See also his allusions to a "rational revolutionary consciousness" and a "politics of revolutionary rationalisation" (2008a, pp. 120-121) with reference to a settled and embedded urban working-class, capable of thinking about the future.
} 
amplified and extended: in this case, to that of industrial production (Sud-Aviation Bouguenais, Renault-Billancourt and elsewhere). As different fields became drawn into the conflict, the taken-for-granted nature of everyday life and the anticipated future became suspended, replaced by an extraordinary experience of "public time": a "vague and almost empty time, common to the different fields" (1988, p. 185). ${ }^{6}$ Resentments, triggered by disappointed expectations at the Sorbonne and elsewhere, began to coalesce, alongside deep-rooted industrial and media conflicts (1988, pp. 170, 174180).

The 1968 academic crisis was marked by disputes over lecturing, teaching, and the traditional (ten-year) doctorat d'Etat. But it was also accompanied by much wider transformations in the presentations of self in everyday life, such as students' use of "tu" (rather than "vous") to professors (1988, pp. 186-188). Bourdieu borrows unexpectedly from Augustin Cournot's model (1861) to frame the structural homologies between different fields and to chart their mounting "synchronization" (1988, p. 174). As Sapiro helpfully notes, Bourdieu shows that many fields were affected by the new post-war demographic patterns and more market-oriented modes of production, resulting in field-specific evolution or revolution, in education as well as changes elsewhere. The effect of such crises is to bind fields together. Put succinctly, the historical "event" or turning-point - whether it is the Dreyfus Affair (1894-1906), the National Revolution (1940) or the May '68 Events - results from the "synchronization of the different fields' temporality and the harmonization of their agenda [...] during the crisis" (Sapiro 2013, p. 266).

This is strikingly clear in Bourdieu's analysis of the Dreyfus Affair, where a crisis provoked by the mistrial for espionage and the wrongful imprisonment of a Jewish army officer for "raisons d'Etat" produced ripple effects within other fields: military, law and-with Zola's newspaper declaration of "J'Accuse!"- the literary field. Together, these schisms created a political crisis resonant with allegations of state betrayal (Bourdieu 1996a, pp. 129-133; 2013, pp. 159-560; 2014, p. 308).

Following such a crisis, wider societal transformation may ultimately be repressed. Such was the case in May '68, not least because of the students' incapacity to engage realistically with workers. But long-lasting field changes may still occur. In the context of '68, Wacquant (1993, p. 11) rightly emphasizes the effect of the subsequent, more conservative, field of power on the grandes écoles themselves, especially the pivotal shift from the prestigious, academically-autonomous Ecole Normale Supérieure - a product of the Third Republic - to the more heteronomous Ecole Normale d'Administration, the power-base of the recently famous "énarques" (Bourdieu 1996b, pp. 197-214). This theory of a "recuperative," "conservative" transformation after 1968 (2015, pp. 482-483) is further elaborated in Bourdieu's postscript to the Rules of Art (1996a), his assessments of neoliberalism and bankers' thought (e.g., 1998b), his study of publishing (1999) and The Social Structures of the Economy (2005).

It is significant that Bourdieu's last great work, Pascalian Meditations (2000a), decisively rejects the notion of amor fati (eternal acceptance of one's social fate) (cf. 2015, pp. 373, 578). Bourdieu had always repudiated the Althusserian view that educational state apparatuses created a supine subordinate class, rendered by the force

\footnotetext{
${ }^{6}$ Bourdieu's categorisation of time owes its phenomenological depth to Husserl's conceptual schema.
} 
of ideology into mere bearers of social structures (see, for example, Bourdieu 1990a, p. 41; 1996, p. 53, Bourdieu and Hahn 1970). But, earlier, he had stressed accommodation or "complicity." He had also frequently contested a mechanistic Marxism that assumed that occupancy of an objective class position is a necessary and sufficient condition for actors to grasp an understanding of their industrial and political interests (1990a, chap. 3; Bourdieu and Eagleton 1992; Bourdieu 2019). In particular, he had referred on numerous occasions to the allure of national political "mythologies," competing with class formation. Drawing not just on Marx but also on Durkheim, Weber, Elias, and Cassirer, Bourdieu has sought to fill these gaps in theoretical understanding with a "generalised materialism" (1990a, p. 17): one that includes analysis of symbolic power and symbolic violence (2016, pp. 792-793, cf. Loyal 2017).

Indeed, following the 1990s' retreat from post-war Keynesianism in the metropolitan heartlands, Bourdieu's empirical work registers a widespread sense of anomie and social suffering. This is provoked not just by unemployment, restricted opportunities, or even the devaluation of degrees, but by a broader deficit in actors' sense of their own social justification. Their lack of symbolic recognition goes alongside underlying relational continuity, not least, of course, the structural efficacy of elites in negotiating their own reproduction. Yet against the mistaken conclusion that Bourdieu is unveiling iron laws of a mechanical force rather than probabilities based on historical relationships (1984, pp. 92-96), he clarifies that his research addresses also enduring margins of liberty (1990a, p. 50; 2000a, pp. 204, 234-235; 2015, p. 448). In certain contexts, such margins for manoeuvre permit innovation, collective resistance, and transformative processes, and not just within segregated fields (2000a, p. 185; 2015, pp. 578-579). Stating explicitly that sociology and history should be united, Bourdieu holds it essential to account both for structuration $^{7}$ and for innovation or change (Bourdieu 1995, pp. 108, 122; 2015, p. 574).

Bourdieu is unusually subtle, compared with other writers such as Clark (2015), in showing how reproduction via privileged families is accomplished. Indeed, the demystification of these mechanisms that favour the privileged - from "sanctuary schools" to social connections - fuels a disenchanted "ethic of suspicion" (1996b, pp. 190, 216$229,360)$. However, it is too restrictive to read the portrayal of social reality in his opus as solely subject to a determinist logic. He also offers an accompanying, internally consistent theory of structural change, although, admittedly, his theory needs further elucidation of the precise situations in which crises emerge and successful symbolic or social revolutions are provoked. As he has argued, such crises may eventually terminate certain patterns of enduring reproduction, whether what is at stake is the peasant world-order, traditional forms of patriarchy, the post-war "trente glorieuses," or the shift from academic to modern painting.

This assessment of a neglected theory of historical change in Bourdieu's works needs to be further defended. I start with his wider view of state transformation, proceed

\footnotetext{
${ }^{7}$ Structuration is conceived in terms of actors' habitus incorporating the collective "historical unconscious (Durkheim) of a class, which is united - via "conductorless orchestration" (Marx) - by the "mastery of a common code" (Bourdieu 1990a, pp. 56 and 59).
} 
to his analysis of prophetic heresies and symbolic revolutions, and end with his mature views on exploitation, suffering, and the denial of symbolic recognition.

\section{On the State (2014, 1989-92 lectures)}

In What Makes a Social Class, Bourdieu (1987a) had already analysed objective gulfs in the possession of capitals, showing how, at certain junctures, those without any capitals champion their socio-economic interests whilst at other times they turn to solidarity based on religious or national allegiances. On the State (2014) further illuminates the emergence in Europe of territorial loyalties tied to such a "national habitus." Indeed, whereas Leibniz had contended that the geometrical intersection of all perspectives is the prerogative of divine vision, Bourdieu maintains, in Durkheimian fashion, that, historically, this privileged geometrical space is that of the state:

The coup d'état from which the state was born [...] attests to an extraordinary symbolic act of force, which consists in getting universally accepted, within the limits of $[\mathrm{a}]$ certain territorial jurisdiction [...] the idea that all points of view are not equally valid, that there is one point of view that is the measure of all points of view, one that is dominant and legitimate. (2014, pp. 68-69, cf. Durkheim 1957, pp. 79-80)

The state presents itself as the general will: in his pithy terms, the state is: "a site made by agents commissioned to state the public good, to be the public good and to appropriate public goods" (2014, p. 86).

The coup d'état from which the centralised modern state is born could only have happened under specific historical circumstances: neither in a clan society where the primitive accumulation of economic capital had not yet been launched nor in feudalism. Indeed, he argues that the centralised state of the seventeenth century preserved the monarch and his chain of interdependent aristocrats but at the cost of feudalism (2014, p. 131). Crucially, he contends that state formation entails not just the monopoly of physical violence but also that of legitimate symbolic violence $(2014$, pp. 125, 128 , 346).

Bourdieu aims to illuminate this via a genetic structuralism or a "negative sociology," free from state-imposed ideas (2014, p. 108). The key transformation is the establishment, within Louis XIV's "king's house," of a new "game": a logic of the state based on a "law of the universal" (see Wacquant, ed., 2005). Hence sociology must theorise a Hegelian state (a legitimate rule underpinned by the principle of universalism) as well as a Marxist state (a regime performing functions for economic capital) (see also 1998a, pp. 35-63). Specifically, "the state is a Janus about which it is impossible to state a positive property without simultaneously stating a negative property" (2014, p. 98): hence "the other side of universalization [of culture] was a dispossession and a monopolization" (2014, p. 101, see also p. 99).

Consequently, certain forms of symbolic domination go alongside the creation of the nation-state, such as the arbitrary devaluation of competing languages. With the unified nation-state and unified language, linguistic codes such as Languedoc or - I might add, 
Glaswegian Scots - became subordinated to that of Parisian French (or Received Pronunciation English) (2014, pp. 119-121, 351). The popular groups, thus marginalised, developed their own "counter-language": forms of "resistance" to the dominant linguistic form (2014, p. 89; 2002, pp. 100-102).

The state reinforces a national habitus. Bourdieu is in accord with Gellner (1983) and with Corrigan and Sayer (1985)) that national social solidarity is enhanced by legitimating certain tastes and awards. These encompass not just popular rituals such as the "Englishness" of drinking tea or beer, but also consecrated culture: French classical theatre, the (British) National Gallery (2014, pp. 152-153), university degrees (2014, pp. 98-99) and the bestowal of national honours or other "symbolic baubles" (Bourdieu 2000a, p. 239). Such collective beliefs extend to official collective memory, as in the longest obituaries, the French Légion d'Honneur or the Panthéon, the mausoleum for honoured citizens (2000a, p. 245).

Bourdieu cites both Marx and Weber to show that the state mystifies the concerns of the dominant classes, discreetly concealing their wider class interests behind the theatrical display of power $(2014$, p. 98). Yet from that very process the concept of the general interest and universal rights is born. This is the invention of jurists (the "State Nobility" or noblesse de robe), located within the expanded seventeenth and eighteenth century legal and bureaucratic fields. From this invention flows the potential for transformative change: "[J]urists are the driving force of the universal, of universalization" (2014, p. 270), with their proclaimed independence and their "capital of words" (2014, p. 331) [...] "[t]hey were the bearers of a rational habitus [...]" (2014, p. 333). And where legal opinion favours change, their coveted autonomy reinforced it:

The logic of these social worlds means that transhistorical things are generated such as science, the law, the [idea of the] universal, that is, things that, though socially produced, are not reducible to their social conditions of production. (2014, p. 96).

Bourdieu analyses such universal rights in conjunction with the State Nobility's prudent monopolisation of its own elite cultural position, not least by the most "primitive" means, the transmission of offices via inheritance (1996b; 2014, pp. 308309). He acknowledges that the resulting exclusion of outsiders verges on the "patrimonialisation" of the public. Nevertheless, the theoretical shift in these lectures to the notion of the legal universal as a transhistorical achievement, born of struggle, is incontrovertible. Heralded in Habitus, Code and Codification (1986; 1990b, pp. 8085 ), the lectures of 1989-92 (On the State) elaborate on the progressive or rational goals for which jurists - nobles and commoners - have undergone sacrifices. It is my contention that this mid-1980s' universalistic perspective represents a critical revaluation on his part, particularly in light of the contemporary extensions of instrumental market reason, or utilitarianism (see Guibentif 2010).

Steven Loyal (2017, pp. 9-10) is right that On the State tends towards a Durkheimian evolutionary model rather than a revolutionary Marxist model. The democratic state, in Bourdieu's view, possesses "fiduciary capital"-frontiers, diplomas. It can even require that you lay down your life for it. But along with this analysis - not too far from Durkheim on the state as social brain-Bourdieu consistently recognises the Marxist truth that: "all these State games serve some people more than others, and serve the dominant more than the dominated" (2014, p. 113; Durkheim 1957, p. 104).

It is in line with this double truth that Bourdieu censures Marx's dismissal of Parliamentary democracy in The 18th Brumaire as merely "analogous to theatre [...] 
a shadow play that obscures the real struggles taking place elsewhere ..." (2014, p. $355)$. On the contrary, democracy as a legal form has become a condition of the dominated classes' participation (2014, p. 359). Yet Bourdieu recognises, alongside this, that the reality of the state is often entirely different from its idealised representation. At critical junctures, their Realpolitik overrides every moral frontier. He had earlier cited the French deep state's systematic use of torture in the Algerian War. In his view, every French town ought to erect admonitory commemorative plaques recalling the State violence of 31st Jan. 1961: the mass drowning of Algerian demonstrators in Paris by police $(2004$ b, pp. $66 ; 2014$, p. 256$){ }^{8}$

The last section of these extraordinary lectures deals with the "rebirth of individualism": the neoliberalism of the late 1970s on. This is nothing less than a state-directed attack on the "cultural revolution" of the late nineteenth century in France, in other words, the initial establishment of the Welfare State. This historical cultural revolution with its "socialization of risk" and "logic of public interest" (2014, p. 363) was in large part constructed by the social sciences, against philosophical individualism (2014, pp. 364-366).

The current assault on public protection entails the reduction of the "social state," even the creation of "civic deserts" in entire lower-class areas, from which hospitals, state housing offices, and other dignified architecture has been removed (Bourdieu et al. 1999, pp. 126-129). This is a highly dangerous policy, for the Welfare State not only serves but controls. It "domesticat[ed] the dominateds" he observes, alluding to what he terms Weber's "Marxist" formulation of these issues (2014, pp. 358-359). For Bourdieu, these changes or "secessions" culminated in a "non-state within the state" (Bourdieu 2014, p. 359). They represent - as Loyal emphasizes - a recent strengthening of the Right Hand of the state against the Left Hand - in other words, the great State Nobility against the minor State Nobility of teachers, social workers, magistrates in lower courts, etc. (Bourdieu et al. 1999, pp. 203-205, 222-226; Loyal 2017, pp. 107108, 113-114; see also Swartz 1998, p. 237). Loyal and Swartz are right, but for Bourdieu the decline of public projects such as social housing can only intensify inner contradictions. Given the state's evident failure to recognise-symbolically or practically - the needs of the subordinate class, such state "secessions" provoke despair and widespread volatility.

Bourdieu's powerful account of the emergence of a universalistic view conceptualises the bureaucracy or state legal officers (jurists) as the guardians of the "national habitus." Yet he simultaneously proffers a "materialis[t]" analysis of the field (2014, p. 342). The legal profession, for example, possesses a specific "interest in disinterestedness," not least its own generational reproduction (2014, p. 342). ${ }^{9}$

This argument for the importance of law was first formulated by his friend, E. P. Thompson (1975), and published in Actes de la recherche en sciences sociales in 1976. For Thompson, the genesis of the British agrarian bourgeoisie (or capitalist gentry) in

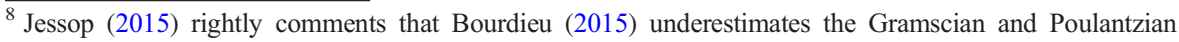
tradition; however, it is incorrect to say that he omits any analysis of the "deep state".

9 According to Bourdieu, the appointment of jurists to a centralised monarchical state has three main "contradictions," of which this is the third. The first is the absolutist monarchy's "pious hypocrisy" in claiming the "public interest" when it appropriated the rights and property of the feudal nobility for its own private interest; the second is the inconsistency of practices requiring that the new jurists be chosen for their talents and industry alone whilst the king's privileges and those of the aristocracy (noblesse d'épée) are inherited.
} 
the eighteenth century meant that, on the one hand, the law became a "superb instrument by which these rulers were able to impose new definitions of property to their even greater advantage, as in the [...] furtherance of enclosure. On the other hand, the law mediated these class relations through legal forms, which imposed, again and again, inhibitions upon the actions of the rulers" (1975, p. 264). The law-notably the Black Act of 1723 - might be "iniquitous." It was beyond the reach of many, but:

If the law is evidently partial and unjust, then it will mask nothing, legitimize nothing, contribute nothing to any class's hegemony. The essential precondition for the effectiveness of law, in its function as ideology, is that it shall display an independence from gross manipulation and shall seem just. It cannot seem to be so without upholding its own logic and criteria of equity; indeed, on occasion, by actually being just. (1975, p. 263) (Thompson's emphasis).

Nothing could distil more clearly what Bourdieu means by the State coming to possess, through the law, a monopoly of symbolic power as well as force.

Bourdieu's analysis of state transformation may have been rooted in his own experience of growing up in the provincial southwest of France (the Béarn), which gave him an unusual insight into the distinctive trajectory of French state centralisation (2004b). In three articles published from 1962 to 1972 (collected in The Bachelors' Ball (2008c)), Bourdieu broaches the analysis later taken up in On the State. In particular, he addresses the decline of the peasant mode of production in the Béarn. Initiated by the recession of the $1880 \mathrm{~s}$, deeply undermined by the post-World War I rise in prices in the national market, and, more recently, by changes in the global market, the movement from a "closed world to an infinite universe" engendered a peasant decline (2008c, p. 174). The Béarn's long independence under its dukes - despite its incorporation within France in the sixteenth century - had endowed a relatively egalitarian provincial world orchestrated around a prosperous and secure peasant class. With its own strategies based on social honour - especially the rule of marriage between peasant equals, with dowry exchange as a prerequisite - the peasant holding was kept whole and relatively prosperous until the late nineteenth century. But since the inauguration of a "critical phase" with World War II, and despite innovations such as agricultural cooperatives, the better-educated women from the hamlets had preferred working in small towns and marrying urban employees (2008c, pp. 185-189). The new marriage preferences hastened the spread of French (as opposed to the peasant patois) and the urban ethos, "accumulating contradictions" or "cognitive costs" for peasant sons, now seen as uneducated and ineducable (2008c, p. 55). Hence the remarkable number $(56 \%)$, post-World War II, of peasant men consigned to a bachelor existence- "reproduction forbidden." 10 The national market leads to the devaluation of the once-autonomous peasant class. Unable to "represent themselves," they become a "class for others," an ignominious "class object," subject to contempt alternating with Heideggerian romanticisation (2008c, pp. 193-200, 1991b).

In the light of On the State, Bourdieu's analysis of an enduring peripheral peasant world after the collapse of seigneurial feudalism should be seen as possessing affinities

\footnotetext{
${ }^{10}$ Bourdieu's ethnography of gendered practices alludes to spinsterhood and the constraints of women's lives with resident mothers-in-law, but the systematic nature of patriarchal control then escaped him. Consequently, he identifies peasant daughters marrying townsfolk as "Trojan horses": the bearers of peasant destruction (2008c, p. 178).
} 
with other accounts of French absolutism, notably Elias's (2006) assessment of the pacification of the feudal aristocracy at the French court and Brenner's (1987) "property relations" approach. In particular, Brenner shows how the success of French peasant rebellions of the thirteenth and fourteenth centuries led to the subsequent sixteenth century emergence of a "centralised political accumulator": protection of the peasantry from the depredations of the feudal nobility, the central extraction of a surplus in the form of State taxes and the growth of a legal administrative class (1987, pp. 289-291). ${ }^{11}$ Yet if, for Brenner, the French State's political absolutism led to the survival, after feudalism, of a peasant agriculture, for him peasant holdings - prone to fragmentation - ultimately ensured only the development of "underdevelopment" (1987, pp. 61-62). For Bourdieu, in contrast, the Béarn farmers resisted fragmentation and continued a peasant "civilization" that, until World War II, could satisfy its sense of honour and material needs.

One last point re On the State. Bourdieu argues that the Great French Revolution of 1789 was enacted politically by radical lawyers rather than by industrialists stepping into the political arena. In this respect he is certainly persuasive. He is also convincing that revolutions are not always cataclysmic (as indeed Thompson had emphasized, in relation to the English agrarian bourgeoisie (1975)). However, as with his earlier accounts of power, he tends to focus too much on symbolic power, so that he sometimes "leaves fundamental relations of force unexamined" (Wacquant 1987, p. 80). Thus, he is less plausible in contending that the French Revolution should ultimately be seen as unnecessary since the jurists and the monarchy had already undermined the old feudal seigneurial class: "I published The State Nobility in 1989" he writes, "to show that the French Revolution essentially did not change anything ...” (2014, p. 346).

On the contrary, the crucial decision is whether the jurists" "bourgeois revolutionary" acts led to an independent centre of economic capital accumulation being set in motion (Davidson 2012, p. 476, see also pp. 482-483). In France-and the French Caribbean-such revolutionary events were the only means by which the remaining feudal dues, rights to slaveholding and arbitrary taxation could be swept away, under the banner of universal "Rights of Man." These prerequisites for the capitalist colonisation of everyday life required a revolutionary break to establish a new set of sociolegal structures and the resulting genesis of a distinctive "economic habitus." 12 Here Neil Davidson is surely worth following when he says:

For Marxists, capitalists exist as "capital personified", their actions constituting a "mere function of capital". [...] Whether the culture of their life world expressed aristocratic or bourgeois values is less important than their integration into [...] capital accumulation, which imposes its own, deeper cultural logic. (2012, p. 372).

\footnotetext{
${ }^{11}$ In sharp contrast, the sixteenth century nobility in England undertook a class "political accumulator" strategy, which also entailed agrarian surplus-extraction via capitalist tenant-farming, heralding the end of the independent peasantry (Brenner 1987, p. 293).

12 Bourdieu defined "economic attitude" or-subsequently_-"economic habitus" as the rational calculation of the means to achieve future wealth, notably the pursuit of profit for its own sake (see 2008a, especially pp. 6869 [1959] and pp. 76-81[1963]).

${ }^{0}$ Note, however, that Durkheim proposed a highly progressive normative model of the modern state: a central democratic forum for deliberation on policies and laws, flanked by democratic secondary associations, amongst which were producer associations resembling modern cooperatives (1957, pp. 62-63; 85-97).
} 
On this specific issue, then, Bourdieu's analysis of the rise of the State and the role of symbolic power in national integration moves too closely within the orbit of Durkheim's evolutionary republicanism. ${ }^{13}$ Yet despite such reservations about his interpretation of the French Revolution, he has made important contributions to the study of social transformation, notably, in On the State, the rise of a legal profession trained in universalistic practices, the establishment of democracy and the origins of the welfare state. Indeed, far from being a theorist of reproduction alone, he has made significant contributions to the historical sociology of social transformation in general and our understanding of France in particular, especially 1848 and 1968 (see 2014, also 1988, 1996a). "Had he wanted," wrote Eric Hobsbawm in his obituary: "he could have been a great historian himself” (Hobsbawm 2016, p. 39).

\section{Manet: Une révolution symbolique (2013)}

Those who lament the absence of transformation in Bourdieu's works often neglect his theory of symbolic revolution in the arts and sciences. Whilst apparently less consequential than political or economic revolutions, for Bourdieu, artists and scientists are nevertheless dangerous because they have the potential to play havoc with the everyday visions and divisions of the social world. They may thus break through the mythology which he believes is so important in helping to secure power (2016, pp. 771-772):

[A] symbolic revolution turns cognitive structures upside down and sometimes, to a degree, social structures. (2013, p. 13).

Bourdieu's final lectures (1999-2000) (Bourdieu 2013), elaborate in greater detail one such historical moment when a gaping rupture appears within social institutions (cf. Bourdieu 1993, pp. 238-266). In his view, Manet's creation of an artistic field — with its comparatively unregulated (or "anomic") institutions - introduced a new "margin for manoeuvre," as did the recently-established modernist literary field constructed by Baudelaire, Flaubert, and Mallarmé (2013, p. 138). Contrary to the Russian formalists' model, these cultural producers did not exercise complete autonomy. Nevertheless, the bohemian space became the equivalent of scientific laboratories for testing new practices $(2013$, p. 71). Its emancipatory potential profoundly affected everyday life, removing one of the legitimating pillars of political power. Within this field, Manet is important as the "heresiarch" (2013, pp. 647-678) who adopts a new kind of painterly manufacture emerging from his revolutionary "technical habitus" and from his Left Republican "ethical habitus" (2013, pp. 82-83).

This portrayal of Manet shows his pioneering "prophetic" role in undertaking an artistic revolution against the French Academy of Fine Art. For what Bourdieu calls his "reflexive provocation towards reflexivity" (2013, p. 64) was more complex and

\footnotetext{
${ }^{13}$ Note, however, that Durkheim proposed a highly progressive normative model of the modern state: a central democratic forum for deliberation on policies and laws, flanked by democratic secondary associations, amongst which were producer associations resembling modern cooperatives (1957, pp. 62-63; 85-97).
} 
intertextual than the largely naturalistic style of the later impressionists. To analyse this rupture, Bourdieu transfers Weber's theory of charismatic prophets to the art world. Thus, he details how the routinized works produced by the painters trained at the Ecole des Beaux Arts precipitated Manet's extraordinary acts of estrangement and transgression. In this visual revolution the banalized "Academic eye" is challenged by a sociallyconstructed "fresh eye": "fresh" because Manet profoundly subverts the sacrosanct Academic hierarchy that had given primacy to Biblical and historical genres. His new painting abandons Academic conventions such as compositional unity or the narrative rule of "making a pyramid" (2013, p. 63); indeed, he is vilified as "mad" for flouting both the Renaissance rule of perspective and the imperative of meticulous "finish," the essence of conservative "pompier" painting (Bourdieu 2016, p. 569).

This new study brilliantly situates Manet's revolutionary subversion by depicting the entire Academic system as a "total institution" (2013, p. 181; cf. Goffman 1961). Seeing Academic painting as equivalent to a state art, not unlike that adopted in 1934 by East European state socialist societies (2013, p. 179), Bourdieu outlines the structures underpinning its orthodox mode of educating, commissioning and exhibiting artists. He emphasizes the sacrosanct Academic hierarchy of artistic subjects. Thus, in large secular works like Déjeuner sur l'Herbe (1863), Manet parodied Giorgione (1477-1510), shockingly depicting a "grisette" (a working — or working-class —woman) sitting, nude, with two elegantly-dressed upper-class men. Tantamount to a proclaimed infraction of Academic decorum and techniques, this painting, like Olympia, was deeply discomforting to the "apparatchiks" of the scholastic professorial elite, who saw themselves as the guardians of legitimate art (2013, p. 243). Indeed, as a "specific revolutionary" (2013, p. 25), Manet subverted the Beaux Arts' monopoly of symbolic goods. He even risked imprisonment or exile, by portraying the "burning issues" of the day, such as the exile of the Paris Communard, Henri Rochfort, or the execution of the Mexican Emperor, Maximilian (2013, pp. 18, 39).

In defamiliarizing the art-historical doxa by these means, Bourdieu follows Mallarmé, who claimed that Manet acted as a scientist, disclosing hidden social reality: Manet "paints the naked truth with a new eye, without presuppositions, unburdened of Academic painters" (Mallarmé, cited 2013, p. 306). Crucially, Manet's art made a double revolution: an artistic revolution in form and a political revolution by a Left Republican against both the state and the French haute bourgeoisie:

This strategy of collision of all the hierarchies is a strategy of a double blow, a blow at once against the Academy and the bourgeoisie." (2013, p. 39).

Note that, for the mature Bourdieu: "the imputation of realism is not exclusive of the imputation of formalism" (2013, p. 61).

Bourdieu's lectures on Manet are subtly different from his initial accounts of the genesis of modernism. He now adds to his earlier "internalist" analysis of the prophetic revolution in form and genres (1993 [1987], pp. 249-250, 264-266), a much fuller materialist or "externalist" analysis of the social relations leading to the changes in the artistic field. Indeed, making another Durkheimian move, he goes even further: a socioanalysis should abolish the "sacred frontier" between the two approaches, externalist and internalist (2013, p. 149). 
In materialist (externalist) terms, Bourdieu had always referred to the super-profits to be made on the market, after the two French 1848 Revolutions (1996a, pp. 48-49). He had also recalled the heightened tensions in the Academy as more and more painters with the bac demanded access to Academic teaching and exhibition space: students from newly-returned aristocratic families as well as from the haute bourgeoisie. Indeed, as he elucidates in other lectures, these objective changes in education represent a crisis in the Ecole des Beaux-Arts overlooked by all other writers on the history of modernism (2016, pp. 574, 584-586). But Bourdieu's externalist analysis now acknowledges and benefits from the path-breaking work of Marxist writers, such as Meyer Shapiro and Tim Clark, the feminist critic, Linda Nochlin, and the social historian, Robert Herbert, all of whom chart the transformations of French capitalism beyond the old artisan-based workshops. In doing so, he addresses the altered modes of production and consumption that are "refracted" (cf. Adorno) in Manet's works. He shows forcefully in these lectures how Paris - with its expanding labour-force of factory-workers, women shop-workers, clerks, and performers - was transformed into the Haussmanised urban metropolis that became the artistic capital of the world.

Bourdieu also explains much more fully now why it was Manet who should have been the prophetic innovator ushering in this "total crisis" (2013, p. 161). Crucially, Edouard was not "at home in the world," despite coming from a high-ranking family, his father being a judge, and his mother the hostess of a salon attended by bankers and politicians. His bac, money, patronage, and bodily demeanour all testified to his class privilege, yet he moved uncomfortably between the elites' dignified houses and the impoverished attics or cafés of Bohemian painters. In a memorable use of a late concept, Manet is stated to possess a profound "habitus clivé" (split or fragmented habitus): he was caught artistically between rebellion and the desire for Salon recognition (2013, pp. $84-85,250)$, the corollary of his passage between the two social worlds (2013, pp. 454-455, 458-459). It is this same fragmented habitus that underlay his iconoclastic vision. For his innovative ways of perceiving and dividing the world represented an outsider's prophetic or revolutionary stance, despite his excellent insider's mastery of art history. Bourdieu reflects:

What is it about those people who whilst totally 'in' [in English] are also totally 'out' [in English]? It's this, a symbolic revolutionary: it's someone who, completely possessed by a system, comes to take possession of it by returning the mastery he possesses against the system. It's very strange. In the advanced forms of autonomous universes, the fields, it's the only form of revolution. (Bourdieu 2013, pp. 377-378).

Bourdieu shows in his Manet lectures an exemplary analysis of an artistic revolution or social change. This combines first, an internalist explanation in terms of the heretical abandonment of orthodox dispositions in his artistic practice (2013, pp. 82-83); second, a materialist or externalist analysis, including the explosive pressures to which the Academy educational structures were subjected, and, third, an explanation at the level of Manet's distinctive personal trajectory. Fabiani is right that other painters, such as Courbet, also made important innovations within the Academic system (2016, p. 178). Yet Bourdieu is convincing that Manet, with his split habitus, was the chief "prophetic" architect of this revolutionary break. 
This distinctive modernist subfield of art was established with new rules and a new anomie. Subsequently, fresh avant-gardes surfaced every generation, anxious to be recognised as genuine artists and solidaristic in defending their distinctive shock of the new. Thus, by the twentieth century, the modernist field is characterised by a forcefield of "permanent revolution," in which consecration occurs with increasing rapidity, bringing commercialisation in its wake (1993, p. 188; 1996a, p. 169; 2015, p. 670). Nevertheless, the work of Manet has an epistemological primacy: the symbolic revolution he made was crucial to the genesis of the modern artistic field itself.

\section{The intelligentsia as a universalistic corporation}

Bourdieu has always stressed the pivotal role of doxa, combining, in this respect, Marx and Husserl. For him, social injustice is frequently "misrecognised" and treated as natural (doxic), part of the social order that goes without saying. Rather than emphasizing solely how ideology mystifies and distorts economic interests, he draws attention to the sources of this natural attitude and the social conditions under which it might be challenged. When do heresies ("heterodoxies") become the new common sense? Here - as we saw with his analysis of Manet's prophetic charisma-Bourdieu develops from Weber a deeper, more relational theory of charismatic power as a source of social dynamism. Crucially, he breaks with the Weberian view that the prophet acquires charismatic power by force of personality or by simply responding to a need for leadership ("supply and demand"). Instead, for Bourdieu, prophetic leaders' critique of the priesthood derives in part from their own lived experience of powerlessness and denigration, especially at the hands of the higher clergy (cf. Berger 1963). There is, moreover, a crucial homology between the prophets' bitter denunciation of the priests' worldliness within the religious field and their critique of the wider field of class power. Marginalised and oppressed themselves, prophets offer new messages of hope to other "left-behind" social groups.

Wider social conditions provoke the masses' turn to prophets, breaking with their usual realistic adjustment. For it is crises - scarcity, war, hyper-inflation, mass migration, or colonisation - that are conducive to symbolic - or cultural-revolutions (1990a, p. 59; 1991a, p. 34). In turn, these cultural revolutions, such as Calvinism, may help to engender wider social transformations (such as the British seventeenthcentury Civil War). They alter the power dynamics among prophets, elites, and masses. Interestingly, before quoting the famous opening of The 18th Brumaire (Marx 1973 [1852], pp. 146-149), he argues:

If there is, doubtless, no symbolic revolution which does not presuppose a political revolution, the political revolution is insufficient by itself to produce the symbolic revolution which is necessary to give it [the political transformation] an adequate language, the condition for its full accomplishment [...]. For as long as a crisis is without its prophet, the schema by which one thinks the upside-down world are still the products of the world to be reversed. (Bourdieu 1991a [1971], p. 37, trans. Amended; see also 2015, p. 579). 
Crucially, Bourdieu contends that, at times of national or international crisis, the prophetic movement may engender a sense of the working class as a "mystical body" - a group unity that is created through "an immense historical labour of theoretical and practical invention" (1985, p. 742, cf. 2019, pp. 116-117). He clarifies further, in his Sociologie Générale lectures, that this is an anti-charismatic conception of social creativity. Paradoxically, "groups create themselves by creating people who create the group" (2019, p. 118).

Like Weber, Bourdieu extends the concept of charisma beyond the religious field. It was often the oral poet who was a charismatic leader or prophetic bearer of new ideas in precapitalist societies (1990a, p. 94; 2016, p. 604; 2019, p. 81). Such bards typically frame a double-coded message: on one level, accessible ideas for the people, on another level, more complex ideas for the educated or leisurely (2008a, pp. 286, 291, 299, 305; 2019 , pp. 21, 81). The lectures enhance this phenomenology of crisis and change:

The sentiment that things tend to persist in their being, that there are careers, probable futures $[\ldots]$, this all totters in the periods of crisis. [...] It's favourable terrain for prophetic intervention. From the moment $[\ldots]$ when one doesn't see too much what is going to happen, the prophet intervenes. It's the poet in precapitalist societies. In societies like ours, a politician comes to the fore. It's not at all an ordinary politician, it's Cohn-Bendit [the student leader of May 1968], it's someone who speaks when everyone else is mute. ..." (2016, p. 139; cf. 2000a, p. 236).

These ruptures in the normal habitus provoke deliberation or despair (2016, pp. 911$912,974)$; yet they also release untapped resources and dispositions, thus creating new social possibilities (2016, pp. 905, 957-958):

[I]t's on the basis of their dispossession of [...] capital at a given moment of time that the dominated can be led to try to transform the structure under certain conditions $[\ldots]$, when the usual agreement between objectivated and incorporated structures has been suspended." (2015, p. 579).

In fact, the ideology of creation is not entirely mistaken, for the prophet "tell[s] the people what they know already, but do not know how to tell themselves. It's a real conversion..." (2016, p. 1073).

Weber had already identified a third group (beyond priests and prophets) in his analysis of change: the precarized or "proletarianized" intelligentsia. Bourdieu adds that wherever there is a struggle over the symbolic, secular intellectuals are crucial for producing weapons that are "[...] coherent and distinctive" (1987b, p. 134) deriving from their professional associations that champion universalist human rights (1989). But - once again — such intellectuals also possess their own symbolic and material interests. Even as intellectuals assert their own disinterestedness, they possess "interests in disinterestedness" (1990b, pp. 110-111; 2000b, p. 106). Further, whilst breaking with Michels' pessimistic elite theory, Bourdieu warns us that intellectuals bring with 
them the dangers of political substitution for the class they represent, especially where educational levels are low (1991c, pp. 174-175, 277 fn. 2; 2019, p. 117). Nevertheless, as Loyal has also emphasized (2017, p.113), he demarcates the "subversive alliances" that can bring social change:

It thus may happen that the interests associated with the dominated position in the field of cultural production lead to subversive alliances, capable of threatening the social order. This occurs when, in the cognitive struggles over the social world, the professional producers of principles of vision and division, globally located in the dominated positions in the field of power [...], engage their cultural capital in struggles that they more or less completely [...] identify with their own struggles in the field of power." (Bourdieu 1996b, p. 387).

Bourdieu continues:

"when, in other words, certain cultural producers (defrocked priests of the millen[arian] movements of the Middle Ages, revolutionary intellectuals, etc.) symbolically abandon the camp of the dominants from whom they derive their power of symbolic construction in order to lend to the dominated their power to constitute the social order [...].” (1996b, p. 387, my italics).

Bourdieu refers here to the subaltern members within the dominated fraction of the dominant class - social workers, teachers, unpromoted academics, etc.- all those undergoing a "double domination" (Bourdieu, p. 2014, p. 326; see also Swartz 1998, p. 237, and Swartz 2013, pp. 240-244). Such groups - including artists - may galvanise others in their claims for social justice (Bourdieu 2000b, pp. 97, 106; Bourdieu and Haacke 1995). ${ }^{14}$

In the late 1990s, Bourdieu defended political action by intellectuals on the basis of specific expertise. There is no incompatibility, he remarks, between the separation entailed in autonomous membership of a social scientific field and collaboration or engagement within wider social movements (2000b, pp. 89-107). Given the imminent destruction of a "social world that has been extraordinarily difficult to establish" at the hands of a neoliberalism that "masks brute economic force," there is a need once again to establish "utopias founded on truth and reason" (2000b, p. 105; also 1998b).

Is the mature Bourdieu surreptitiously reinstating Sartre's "consciousness-raising" (1990a, p. 45)? I think not, partly because he always emphasized the incorporation of domination, requiring austere learning to retrain our whole being - body and mind - to instil fresh customs and habits (2000, pp. 12, 108; 2001, p. 40). Moreover-unlike Sartre-he emphasizes the collective social supports for "authentic intellectuals," including the collegial germination of ideas (1990a; 2008b). He critiques the latter's extravagant claims to universal knowledge, insisting on the "specific intellectual," with

\footnotetext{
${ }^{14}$ Swartz (1998) is right, however, when he says that Bourdieu glosses over when this is more likely to happen - why some fields rather than others have subordinate actors who ally themselves with workers in a "politics of collective mobilisation" (1998, p. 136).
} 
bounded expertise, not Sartre's fantasy of the "total intellectual" (1980, p. 12). He was always mindful, too, of the demographic and other non-normative conditions that produced crises, as in the expanded nineteenth-century student population that tolled the doom of Academic art education (cf. 1990a, p. 45).

\section{Exploitation and margins of freedom}

Bourdieu's last significant theoretical formulations - Pascalian Meditations - can be linked to these earlier lectures. In particular, the two volumes of lectures in Sociologie Générale are stirring because they emphasise vividly sociology's role in bringing about reflexivity, thus ending what William Blake called our "mind-forged manacles." Reflexive awareness is difficult_-and never absolute-because we are determined more than most people would like to believe:

If sociology teaches, if it publicizes itself, but equally if many fight against it and watch that it is as little diffused as possible, it is also because it aims to diffuse a privilege [...] [A]s sociology gives a knowledge of determinisms and thus a possibility of liberty in relation to determinisms, to write sociologically, or to tell everybody about it [...] is to work to diffuse, to universalize, the possibility of a liberty. (2015, p. 455, see also p. 448).

He continues: "I am going to go to the end of the prophetic logic [...] My project, in effect, is to give [...] a manner of thinking that people can put into practice, including against what I say...” (2015, p. 455; cf. Bourdieu 2000b, p. 104).

Earlier, in 1970, he had clarified this relationship between social science and action: "The sociologist only helps in raising awareness: afterwards people act" (Bourdieu and Hahn 1970, p. 20, see also pp. 14-15 and 21).

This concept of practical action opposes both final causation (teleology) and a mechanistic materialism (cf. 1990a, ch. 3). Like Walter Benjamin, he was critical of those economistic accounts that had turned Marxism from social science into a predetermined logic of necessary historical stages. Like Marx, he alerts us to the powerful consequences of a theory gripping the minds of the masses or "theory effects" (Bourdieu 2019, pp. 69, 77, 81)). Yet he still identifies with the tradition of an authentic historical materialism as though this were a rich hidden vein of gold (1990b, p. 13). In major works and throughout his lectures, he emphasizes that his theory of practice, with its element of improvisational liberty, embodies the active aspect of humans' being within the world (1990a, pp. 21, 57).

What then does this "margin of liberty" or capacity to "improvise" mean for him? First, those actors who lack all capitals are often subject to "misrecognizing" power. Yet such actors are also more prone to adopt an alternative vision, the belief that "another world is possible." Misrecognised forms of power may sometimes induce resignation or even complicity, but they also engender social suffering: indeed, suffering more often than happiness (Bourdieu et al. 1999; Bourdieu and Eagleton 1992, pp. 111-112). Further, whilst there are deep affinities structuring the preference of specific groups for 
specific ideas, there continue to be significant "margins of liberty" as to how such suffering is expressed (2016, p. 1074). Indeed, one of the elements that characterises Bourdieu's distinctive approach is his insistence that the habitus - determined by objective position in relation to the possession of capitals - is endowed with a "relative autonomy" as to how symbolic power impinges on it and thus shapes practices:

the move into politics occurs when we leave the doxa [...] and move to an orthodox or heterodox experience $[\ldots]$ It is in this $[\ldots]$ that there is room for manoeuvre." (2019, p. 72).

Second, in societies where cultural fields still possess functional autonomy, scientific or other peers have a margin for manoeuvre. They can decide for themselves which research projects to support, disregarding other types of determinism, such as class, religion, or ethnicity (2016, pp. 594-595). A scientist is not fully at liberty: she or he is determined by the social rules of scientific method (2004a, p. 52), but is free to use her scientific capital and habitus to critique - say - the consequence of state policies.

Thirdly, and more generally, those actors who possess extraordinary cultural capital in any particular field will also possess the potential to restructure that field and to revalue its values. We have seen this in the case of Manet's symbolic revolution, but it applies elsewhere - to Newton or to Baudelaire for example.

It should finally be noted that the late Pascalian Meditations has been somewhat overlooked as an analysis of objective contradictions, particularly of class and race. For example, drawing on Capital Vol. III, Bourdieu clarifies here that average profit rates are maximized when labour is at its most mobile, when the labour process has been most deskilled and when the artisanal work-ethic of the labourer counts for little (2000a, p. 202). He endorses Marx's view that the pathos of capitalist labour lies in the fact that the exploitative extraction of surplus value typically remains concealed (2000a, pp. 202-203). Indeed, in Sociologie Générale II, he states that the theory of surplus value counts as one of the great "foundations" of social science; yet laments that Marx fails to integrate into it a scientific analysis of the resistances to diffusing it (2016, pp. 105-106; 2019, p. 66). Ultimately, a deep affinity exists between the position of the dominated and social science:

$[\mathrm{O}]$ nce scientific truth is produced, those in the space who are dominated hear it more clearly, and immediately make use of it, reworking and recycling it so that it expresses them more fully. (2019, p. 44; cf. 2019, p. 73).

It is true that he strikingly engages the Jansenist, Pascal, to explain the somaticallyembedded "customs of the heart" that lead actors to resilience in the face of (misrecognised) injustice. But he also elucidates further the phenomenology of alienation when symbolic recognition or honour is withheld: most notably, those injuries of social class and race that provoke discrimination and unemployment. Thus, those devoid of work discover that unemployment becomes "dead time":

Deprived of [work] they can only experience the free time that is left to them as dead time, purposeless and meaningless. If time seems to be annihilated, this is because employment is the support, if not the source, of most interests, 
expectations, demands, hopes and investments in the present, and also in the future or the past that it implies, in short, one of the major foundations of illusio in the sense of involvement in the game of life... (2000a, p. 222; cf. also 2008, p. 204).

The symbolic violence of racism leads to severance of the usual predictable connections between present and future. It is this, for example, that compels African-American parents to make their children fear authority: here he draws poignantly on James Baldwin's The Fire Next Time (1963) — as true now as at the time of writing:

'Long before the black child perceives this difference [...] he has begun to react to it, to be controlled by it. Every effort made by the child's elders to prepare him for a fate from which they cannot protect him causes him secretly, in terror, to begin to wait, without knowing that he is doing so, his mysterious and inexorable punishment. He must be "good" not only to please his parents [but because] behind their authority stands another — nameless and impersonal, infinitely harder to please, and bottomlessly cruel.' (Baldwin cited 1993, p.170).

In Bourdieu's view, such objective sources of suffering become unbearable when there is structural change between anticipated practices and the new social reality within a given social position, resulting in hysteresis (1996, p. 186) ${ }^{15}$ or a "maladjusted habitus." Produced by massive socio-economic changes or "social ageing," this habitus creates a sense of "contre-temps": of living in a different time, including a potential awareness of countervailing forces $\left(2015\right.$, p. 381). ${ }^{16}$ In other words, pace Fabiani's (2016, pp. 83-86) critique of Bourdieu's "oversocialised" conception of habitus, the subordinate classes for Bourdieu may tend in general towards resignation in response to their pain but not to certain specific changes, with the resulting mismatches of habitus.

This does not imply that workers will necessarily take industrial action or act politically. Bourdieu's earliest work, on colonial Algeria, should remind us that the most precarious-like those now in the gig economy on temporary or zero-hours contracts - are so preoccupied with the struggle against destitution that they are often too desperate to act in organised opposition (Bourdieu 2008a, pp. 75-111, 153-191, 213-235). Indeed, in 1999, he describes this declining power of unionised labour as itself "the end of a world" (Bourdieu et al. 1999, pp. 317-320). Yet, in some cases, temporary workers can mobilise effectively despite such obstacles, as shown in Jain's Bourdieusian study of the Suzuki car factory at Manesar (India) (2016). For where significant structural "rationalisation" has occurred (as in Manesar with the changed line speed, reduced holidays, and greater sanctions), this may be sufficient to induce a

\footnotetext{
${ }^{15}$ He emphasizes particularly the "misfirings" of habitus when, for example, students with degrees do not get the jobs they anticipated: a mismatch that applies particularly to educated African-Americans in the United States. Others have explored further the consequences of this. Thus Lamont (2000) for example, has conducted a powerful empirical study into discrepancies in the readiness to perceive inequality as injustice as between African-American workers and white American workers (working- and middle class), and as between those in America as contrasted with France; she elicits fruitfully not just workers' moral views but their carefully-constructed philosophies.

${ }^{16}$ As Bourdieu remarks on numerous occasions, this is "the Don Quixote effect," referring to Sancho Panza's naïve expectation of feudal paternalism (quoted 2015, p. 549 n. 2; cf. also 1990a, p. 62; 1990b; p. 90) On such a Don Quixote effect, see also Marx's letter to Lassalle and Marx's article in the New York Daily Tribune, 11 Jan 1858, both cited in Prawer (1976, pp. 215, 240).
} 
sense of crisis. Workers then come to re-evaluate heterodox beliefs, in the latter case, adopting a "fuzzy logic" combining revolutionary theory with Hinduism (2016, p. 223).

\section{Conclusion}

Bourdieu's work has been misjudged as a determinist theory of pitiless social reproduction alone. This accusation - especially common in the Anglophone sphere-may be linked to the rhythm of his translations. As Gorski suggests, Bourdieu first became known for works that focus on the long-lasting reproduction of dominant families (Gorski 2013, p. 3). ${ }^{17}$ This simplistic interpretation of his thought has been accentuated due to his misattribution to "postmodernism," along with anti-Enlightenment theorists like Baudrillard or the later Lyotard (cf. Calhoun 1995, pp. 132-135).

I hope to have shown that Bourdieu possesses a complementary analysis to reproduction, namely a compelling theory of crises and "prophet"-led symbolic revolutions, sometimes within one field, sometimes harmonised or synchronised across fields; this is, moreover, integrated with a materialist account of interests. Particularly where the dominants in the wider field of power are fractured, such crises tend to suspend doxa and promote transformative change (as in the case of the wars which preceded the Russian 1917 Revolution and the Portuguese 1974 "Carnation Revolution"). Bourdieu sees material position - including the absence of all capitals - as necessary but not sufficient to provoke interests in a movement for wider societal change across economic and political fields. Rather a heterodox prophetic figure (or figures) must emerge who offers an imaginative new vision and division of the world. This alone can galvanise men and women into undertaking the long labour of forging a united group — as in the historical labour movement - sometimes against powerful alternative nationalist currents (1985; 1987; and 2019, pp. 116-117).

Allying himself with historians like Charle, Chartier, and Darnton, Bourdieu's account of societal transformation is internally consistent, but never fully realised in detail: an initial architectural drawing, as it were, rather than a fully-specified, threedimensional architectural model. However, sadly, it remains a common charge that Bourdieu's theory of practice is severely marred by its alleged ultra-determinism. Yet which positivist determinist would write:

We seek to lift the lid which bears down on the heads of the poorest. Just as medicine has liberated us from infantile mortality [...] so our education ought to avoid the mutilation that the current social system inflicts from generation to generation on the underprivileged. (Bourdieu and Boltanski 1975, p. 11) (my italics).

Further, which unremitting determinist would stress a countervailing potential? Yet the first pricks of the habitus - for example, urging those with capitals ceaselessly to enrich and pass down their privileges - can be countered by learnt reflexivity (Bourdieu

\footnotetext{
${ }^{17}$ The Algerians (1962), then Reproduction (1977), The Inheritors (1979) Algeria 60 (1979), Outline of a Theory of Practice (1977), and Distinction (1984). Yet it is notable that, even in these works, reproduction is accompanied by other social transformations. Distinction famously differentiates between the "punitive discipline" up to the 1960s and the later soft discipline - the "velvet glove" of consumer seduction and associated market sanctions - whilst The State Nobility documents concurrently the changing hierarchical position of the various grandes écoles.
} 
and Wacquant 1992, pp. 136-137; 2012). And which fatalistic determinist would elaborate on the margin for freedom and resistance as Bourdieu did, saying: "All progress in the knowledge of necessity is progress in possible liberty" (Bourdieu and Chartier 2010, p. 39)? Finally, which proponent of an unassailable iron law of reproduction would defend a "reasoned utopia,"18 accept an Ernst Bloch Prize, and lament that utopianism now [is] so often "discredited, dismissed and ridiculed in the name of economic realism" (Bourdieu 1998b, p. 125; 2000, p. 103; Bourdieu and Chartier 2010, p. 17)?

I would argue that Bourdieu's entire works exemplify with unusual originality and synthesizing power, Gramsci's "Pessimism of the intellect, optimism of the will". As he remarked, in Gramscian vein:

[T] he ethnosociologist is a sort of organic intellectual of humanity who, inasmuch as he is a collective agent, can contribute to denaturalising and defatalising human existence by putting his competence in the service of a universalism rooted in the understanding of particularisms. (Gramsci 2008a, p. 355).

Open Access This article is licensed under a Creative Commons Attribution 4.0 International License, which permits use, sharing, adaptation, distribution and reproduction in any medium or format, as long as you give appropriate credit to the original author(s) and the source, provide a link to the Creative Commons licence, and indicate if changes were made. The images or other third party material in this article are included in the article's Creative Commons licence, unless indicated otherwise in a credit line to the material. If material is not included in the article's Creative Commons licence and your intended use is not permitted by statutory regulation or exceeds the permitted use, you will need to obtain permission directly from the copyright holder. To view a copy of this licence, visit http://creativecommons.org/licenses/by/4.0/.

\section{References}

\section{NB Actes.... Below refers to Actes de la Recherche en Sciences Sociales}

Baldwin, J. (1993). [1963] The Fire Next Time, New York: Vintage International.

Berger, P. (1963). Charisma and religious innovation: The social location of Israelite prophecy. American Sociological Review, 28(6), 940-950.

Bourdieu, P. (1980) Sartre, London Review of Books, 2, Nov 20th, 11-12.

Bourdieu, P. (1984). Distinction. London: RKP.

Bourdieu, P. (1985). [1984] social space and the genesis of groups. Theory and Society, 14(6), 723-744.

Bourdieu, P. (1986). Habitus. Code and Codification. Actes..., 64(Sept), 40-44.

Bourdieu, P. (1987a). What makes a social class? On the theoretical and practical existence of groups. Berkeley Journal of Sociology, 32(1), 1-18.

Bourdieu, P. (1987b). [1971] legitimation and structured interests in max Weber's sociology of interests. In S. Lash \& S. Whimster (Eds.), Max Weber, rationality and modernity (pp. 119-136). London: Allen and Unwin.

\footnotetext{
${ }^{18}$ Rational utopianism, as opposed to mere wish-fulfilment, is in tune with the objective possibilities of the epoch whilst avoiding "philistine platitudes concerned essentially with facts." Inimical to bankers' economic realism, which makes "money the gauge of all things," it opposes both a simplistic "autonomism" in which objective contradictions are alone sufficient to revolutionize the world and "activism for its own sake [...] based on an excess of optimism" (1998b, p. 128).
} 
Bourdieu. (1988). Homo Academicus. Cambridge: Polity.

Bourdieu, P. (1989). The corporatism of the universal. Telos, 81(Fall), 99-110.

Bourdieu, P. (1990a). The logic of practice. Cambridge: Polity.

Bourdieu, P. (1990b). In other words. Cambridge: Polity.

Bourdieu, P. (1991a). [1971] Genesis and structure of the religious field. Comparative Social Research, 13, 144.

Bourdieu, P. (1991b). The political ontology of Martin Heidegger. Cambridge: Polity.

Bourdieu, P. (1991c). Language and symbolic power. Cambridge: Polity.

Bourdieu (1993). The Field of Cultural Production, R. Johnson (Ed.). Cambridge: Polity.

Bourdieu, P. (1995). Sur les Rapports entre la Sociologie et l'Histoire en Allemagne et France. Actes..., 106$107,108-122$.

Bourdieu, P. (1996a). The rules of art. Cambridge: Polity.

Bourdieu, P. (1996b). The state nobility. Cambridge: Polity.

Bourdieu, P. (1998a). Practical reason. Cambridge: Polity.

Bourdieu, P. (1998b). A reasoned utopia and economic fatalism. New Left Review, 227, 125-130.

Bourdieu, P. (1999). Une révolution conservative dans l'édition. Actes.... 126-127, 2-28.

Bourdieu, P. (2000a). Pascalian meditations. Cambridge: Polity.

Bourdieu, P. (2000b). Propos Sur le champ politique. Lyon: Presses Universitaires.

Bourdieu, P. (2001). Masculine domination. Cambridge: Polity.

Bourdieu, P. (2004a). Science of science and reflexivity. Cambridge: Polity.

Bourdieu, P. (2004b). Esquisse pour Une auto-analyse. Paris: Seuil.

Bourdieu, P. (2005). The social structures of the economy. Cambridge: Polity.

Bourdieu, P. (2008a) Esquisses algériennes. T. Yacine (Ed.). Paris: Seuil.

Bourdieu, P. (2008b). In F. Poupeau \& T. Discepolo (Eds.), Political Interventions. London: Verso.

Bourdieu, P. (2008c). The bachelors' ball. Chicago: University of Chicago Press.

Bourdieu, P. (2013). Manet: une révolution symbolique, (1999-2000, with M.- C. Bourdieu). Paris: Seuil, Raisons d'Agir.

Bourdieu, P. (2014). On the State (1989-1992). Cambridge: Polity.

Bourdieu, P. (2015). Sociologie générale (Vol. I (1981-3)). Paris: Raisons d'Agir, Seuil.

Bourdieu, P. (2016). Sociologie générale (Vol. II (1983-6)). Paris: Raisons d'Agir, Seuil.

Bourdieu, P. (2019). Classification struggles. Cambridge: Polity.

Bourdieu, P. And M. Mammeri (2008) Dialogue sur la poésie orale en Kabylie in P. Bourdieu (2008a) Esquisses Algériennes, T. Yacine (Ed.) (pp.285-319). Paris: Seuil.

Bourdieu P. and L. Boltanski (1975) Le Fétichisme de la langue, Actes..., 4, 2-32.

Bourdieu, P., \& Boltanski, L. (1978). Changes in the social structure and changes in the demand for education. In S. Giner \& M. S. Archer (Eds.), Contemporary Europe (pp. 197-227). London: Routledge and Kegan Paul.

Bourdieu, P., \& Chartier, R. (2010). Le sociologue et l'historien. Marseille: Agone.

Bourdieu, P., \& Eagleton, T. (1992). Doxa and common life. New Left Review, 191, 111-121.

Bourdieu, P., \& Haacke, H. (1995). Free exchange. Cambridge: Polity.

Bourdieu, P., \& Hahn, O. (1970). La théorie. VH [Victor Hugo] Paris: Editions Esseliers, 101(2), $12-21$.

Bourdieu, P., \& Passeron, J.-C. (1990). Reproduction in education, society and culture. London: Sage.

Bourdieu, P., \& Wacquant, L. J. D. (1992). An invitation to reflexive sociology. Cambridge: Polity.

Bourdieu, P., et al. (1999). The weight of the world. Cambridge: Polity.

Brenner, R. (1987). The agrarian roots of European capitalism. In T. S. Aston \& C. H. E. Philpin (Eds.), The Brenner debate (pp. 313-327). Cambridge: University of Cambridge.

Burawoy, M. (2012). The roots of domination: Beyond Bourdieu and Gramsci. Sociology, 46(2), 187-206.

Burawoy, M., \& von Holdt, K. (2012). Conversations with Bourdieu. Johannesburg: Wits University Press.

Calhoun, C. (1995). Critical social theory. Oxford: Blackwell.

Callinicos, A. (2006). The resources of critique. Cambridge: Polity.

Clark, G. (2015). The son also rises. Princeton: Princeton University Press.

Corrigan, P., \& Sayer, D. (1985). The great arch. Oxford: Blackwell.

Davidson, N. (2012). How revolutionary were the bourgeois revolutions? Chicago: Haymarket.

Durkheim, E. (1957). Professional ethics and civic morals. London: Routledge and Kegan Paul.

Elias, N. (2006). The court society. Dublin: University College Dublin Press.

Fabiani, J.-L. (2016). Pierre Bourdieu: Un structuralisme hérö̈que. Paris: Seuil.

Feraoun, M. (1962). Journal 1955-1962. Paris: Seuil.

Gellner, E. (1983). Nations and nationalism. Oxford: Blackwell.

Goffman, E. (1961). Asylums. New York: Doubleday Anchor. 
Gorski, P. (2013). Bourdieu as a theorist of change. In P. Gorski (Ed.), Bourdieu and historical analysis (pp. 115). Durham: Duke University Press.

Gouldner, A. W. (1971). The coming crisis of Western sociology. London: Heinemann.

Guibentif, P. (2010). Foucault, Luhmann, Habermas, Bourdieu: Une génération repense le droit. Paris: L.G.J.D.

Heinich, N. (2007). Pourquoi Bourdieu? Paris: Gallimard.

Hobsbawm, E. (2016). Pierre Bourdieu: Critical sociology and social history. New Left Review, 101(Sept-Oct), $37-47$.

Jain, S. (2016). Worlds within and beyond words: Bourdieu and the limits of theory. In D. Robbins (Ed.), The Anthem companion to Pierre Bourdieu (pp. 201-225). Oxford: Anthem Press.

Jessop, B. (2015). The Central Bank of Symbolic Capital: Bourdieu's On the State, Radical Philosophy. SeptOct., 33-41.

Joly, M. (2018). Pour Bourdieu. Paris: C.N.R.S. Editions.

Lamont, M. (2000). The dignity of working men. Cambridge: Harvard University Press.

Lareau, A., \& Weininger, E. (2003). Cultural Capital in Educational Research: A critical assessment. Theory and Society, 32(5/6), 567-606.

Latour, B. (2007). Reassembling the social. Oxford: Oxford University Press.

Loyal, S. (2017). Bourdieu's theory of the state. London: Palgrave.

Marx, K. (1973). [1852] the eighteenth Brumaire of Louis Bonaparte. In D. Fernbach (Ed.), Karl Marx: Surveys from exile (pp. 143-249). Harmondsworth: Penguin.

Prawer, S. S. (1976). Karl Marx and world literature. Oxford: Clarendon Press.

Sapiro, G. (2013). Structural history and crisis analysis. In Gorski (Ed.), Bourdieu and historical analysis (pp. 266-285). Durham: Duke University Press.

Scott, J. C. (1987). Weapons of the weak: Everyday forms of peasant resistance. New Haven: Yale University Press.

Swartz, D. (1998). Culture and power: The sociology of Pierre Bourdieu. Chicago: University of Chicago Press.

Swartz, D. (2013). Symbolic power, politics and intellectuals. Chicago: University of Chicago Press.

Thompson, E. P. (1975). Whigs and hunters. London: Allen Lane.

Thompson, E.P. (1976). Modes de Domination et Revolutions en Angleterre. Actes..., 2-3, 135-181.

Verdès-Leroux, J. (1998). Le savant et la Politique. Paris: Grasset.

Wacquant, L. (1987). Symbolic violence and the making of the French agriculturalist: An enquiry into Pierre Bourdieu's sociology. Australian and New Zealand Journal of Sociology, 23(1), 65-88.

Wacquant, L. (1993). On the tracks of symbolic power: Prefatory notes to Bourdieu's State Nobility. Theory. Culture and Society, 10(3), 1-17.

Wacquant, L. (Ed.). (2005). Pierre Bourdieu and democratic politics. Cambridge: Polity.

Weber, M. (1978). In G. Roth \& C. Wittich (Eds.), Economy and society. Berkeley: University of California Press.

Publisher's note Springer Nature remains neutral with regard to jurisdictional claims in published maps and institutional affiliations.

Bridget Fowler is Emeritus Professor of Sociology at the University of Glasgow, specialising in social theory, Marxist-feminism, and the sociology of culture. She has had a long-term interest in the thought of Pierre Bourdieu, whose ideas she has taken up in various articles and books including The Alienated Reader (Harvester Wheatsheaf 1991); Pierre Bourdieu and Cultural Theory: Critical Investigations (Sage 1997), and an edited volume, Reading Bourdieu on Society and Culture (Blackwell 2000). She has also applied Bourdieusian theory quite extensively, including to the empirical study of obituaries (see The Obituary as Collective Memory, Routledge 2007), the cinema (see Bourdieu, Field of Cultural Production and Cinema: Illuminations and Blind Spots, in ed. Guy Austin, New Uses of Bourdieu in Film and Media Studies, 2016, London, Berghahn) and architecture (see Fowler and F. Wilson, Women Architects and their Discontents, Architectural Theory Review, 2013,17(2-3), pp. 199-215. She continues to work on Bourdieu, as well as on his collaborators, such as Luc Boltanski (on whom she has published also), and his former doctoral students, notably Gisèle Sapiro and Pascale Casanova. 


\section{Affiliations}

\section{Bridget Fowler $^{1}$}

1 Sociology, School of Social and Political Sciences, College of Social Sciences, Adam Smith Building, University of Glasgow, G12 8RT, Glasgow, UK 